\title{
Survey of Websites on Cornelius Castoriadis
}

\author{
by Anders Ramsey, Andrea Gabler, Harald Wolf and Ingerid Straume
}

\section{Association Castoriadis (AC)}

http://www.castoriadis.org/fr/default.asp

AC was founded in 1998 by students, researchers, psychoanalysts, political activists, friends and members of Castoriadis' family. AC aims at spreading worldwide Castoriadis' work and ideas and takes a strong interest in publishing the posthumous production of Castoriadis. AC organises and supports different events on the intellectual life of Castoriadis. Also, AC holds a comprehensive archive of Cornelius Castoriadis' works and an extensive online catalogue. Additionally, AC comprises freely accessible texts and multimedia materials by and on Castoriadis.

\section{Castoriadis Blog (CB)}

http://castoriadis.blogspot.com/

Members of the Nordic Summer University's Study Group \#8 called “Creation, Rationality and Autonomy" started CB in 2006 as an "experiment in communication and joint research" (all excerpts are from the blog's main page). CB aims at facilitating discussions on the philosophy and political thought of Cornelius Castoriadis. "Castoriadis-related comments are welcome: book reviews, conference notices, thoughts from your ongoing work", thus making use of the opportunities that online communication can offer: "The advantage with blogging is that we do not have to wait for the next conference to discuss our ongoing work. The floor is yours."

\section{Cornelius Castoriadis Agora International Website (CCAI)}

http://www.agorainternational.org/

CCAI is an extensive website on Castoriadis, initialised by his long-time English translator David Ames Curtis. CCAI aims at connecting people who are concerned with Castoriadis and his project for autonomy. Especially worth mentioning is the section entitled "Bibliographies and Webographies": "The purpose of this continuing bibliographical project is to let people know what has been published by and about Castoriadis so far, to keep track as new material becomes available, and to encourage people worldwide to use these bibliographies as tools for building an international agora that will contribute to the advancement of the project of autonomy." Furthermore, the Agora International archive keeps copies of texts for all interested researchers. The current number of free subscribers to CCAI is more than 1150; in this way, they are informed regularly on new activities, relevant announcements, and bibliography / webography updates.

\section{Verein für das Studium und die Förderung der Autonomie (VSFA)}

http://www.autonomieentwurf.de/ 
The German association for the study and the advancement of autonomy aims at promoting the knowledge and the study of Castoriadis' work in the German-speaking world. VSFA tries to participate in developing and refreshing his project for autonomy in a theoretical as well as in a practical way. To this end, meetings, film projections, conferences and other events are organised by VSFA. Another significant undertaking of VSFA is the translation and publication of select works by Castoriadis. So far three volumes have already been published. The website contains a commented presentation of Castoriadis' autonomy project, a blog, and an archive with texts by and about Castoriadis as well as his France-based militant political group "Socialisme ou Barbarie".

\section{Costis.org}

\section{Lightning Archive (CLA)}

http://www.costis.org/x/castoriadis/index.asp

Though not devoted to Castoriadis only, CLA offers a selection of freely accessible etexts by and on Castoriadis in English, French and Greek. Other authors whose work appears in CLA are: H. Chopin, J. Donguy, R. Filliou, R. Francken, A. Kaprow, J.F. Lyotard, and K. Schwitters.

\section{Marxists.org (MX)}

http://www.marxists.org/francais/general/castoriadis/index.htm

MX includes a French section of the Marxists Internet Archive (Bibliotheque

Générale) and contains links to some early works of Castoriadis (1946-1956). 